\title{
Importance of discards from the English Nephrops norvegicus fishery in the North Sea to marine scavengers
}

\author{
T. L. Catchpole ${ }^{1, *}$, C. L. J. Frid ${ }^{2}$, T. S. Gray ${ }^{3}$ \\ ${ }^{1}$ Centre for Environment Fisheries \& Aquaculture Science (CEFAS), Pakefield Road, Lowestoft NR33 0HT, UK \\ ${ }^{2}$ Univeristy of Liverpool, School of Biological Sciences, Liverpool L69 3BX, UK \\ ${ }^{3}$ University of Newcastle-upon-Tyne, School of Geography, Politics and Sociology, Newcastle-upon-Tyne NE1 7RU, UK
}

\begin{abstract}
Discards refer to that part of the catch which is returned to the sea during commercial fishing operations. Organisms that do not survive the discarding process can provide an additional food source to scavenging species. The aim of this study was to determine whether the quantity and quality of discarded material from the intensively fished English Nephrops norvegicus fishery is such that it has a positive effect on marine scavenger populations. Field studies were used to identify marine scavenger species and estimate their abundance. Discard experiments combined with data from commercial vessels provided estimates of the partitioning of discards between aerial and marine scavengers and the spatial distribution of discarding. A bioenergetic model was devised to evaluate the importance of discards to marine scavengers. Seabirds utilised an estimated $57 \%$ of the discarded material ${ }_{i}$ most discarding ( $83 \%$ ) took place over the fishing grounds. Species identified as marine discard scavengers included Liocarcinus depurator, Asterias rubens, Neptunea antiqua, Pagurus bernhardus, Carcinus maenas, Cancer pagurus and Myxine glutinosa. The hagfish M. glutinosa was the most abundant scavenger, and made up $79 \%$ by weight of all identified marine scavengers on the fishing grounds. The energy available from discards could potentially provide the identified marine discard scavengers on the fishing grounds with $37 \%$ of their energetic requirements during the fishing season. This level of contribution is probably sufficient to allow larger populations of these scavenging species to exist than would otherwise be possible.
\end{abstract}

KEY WORDS: Discards $\cdot$ Scavengers $\cdot$ Nephrops norvegicus $\cdot$ Bioenergetic model Resale or republication not permitted without written consent of the publisher

\section{INTRODUCTION}

Discards refer to that part of the catch which is not retained on board during commercial fishing operations and is returned to the sea. Discarding of marine organisms is a widespread feature of commercial fishing operations. The proportion that is discarded constitutes approximately $27 \%$ of global fish catches (Alverson et al. 1994).

Organisms that do not survive the discarding process subsidise marine food webs. The additional food source, which would not be available under natural conditions, creates a potential to promote the success of species that utilise discards (Britton \& Morton 1994,
Jennings \& Kaiser 1998). A wide range of scavengers including seabirds, fishes and benthic invertebrates are known to feed on discards (Britton \& Morton 1994, Garthe et al. 1996, Yamamura 1997, Bozzano \& Sarda 2002).

Discards are considered responsible for the growth in populations of several scavenging seabird species including the fulmar Fulmarus glacialis, the herring gull Larus argentatus and the lesser black-backed gull L. fuscus (Camphuysen et al. 1995, Garthe et al. 1996). Seabirds feed predominantly on roundfish discards and less so on discarded flatfishes and invertebrates, which are generally less buoyant and more difficult for the birds to handle (Tasker et al. 2000). In the North 
Sea, it is estimated that seabirds consume $50 \%$ of discarded material (Jennings \& Kaiser 1998) and enough to potentially support over 6000000 birds (Camphuysen \& Garthe 2000).

Fishing activities provide 2 sources of food for fishes and invertebrate scavengers: firstly from the discarded material not utilised by seabirds, and secondly from material left on the sea floor displaced, damaged or killed by contact with fishing gear (Jennings \& Kaiser 1998). Fish have been shown to consume damaged or exposed animals in the trawl track (Kaiser \& Spencer 1994, 1996), but there is less direct evidence that they utilise discards. While some fish species are attracted to discard material (Kaiser \& Spencer 1996, Groenewold \& Fonds 2000), it has been proposed they can be out-competed by the benthic invertebrates feeding on discards on the sea floor (Wieczorek et al. 1999).

There are many scavenging benthic invertebrates (for review see Britton \& Morton 1994). In the North and Irish Seas, starfish, whelks, crabs and amphipods are the most frequently identified benthic discard scavengers (e.g. Ramsey et al. 1997, Lindeboom \& de Groot 1998, Wieczorek et al. 1999, Bergmann et al. 2002a). However, in contrast with seabirds, the evidence for the expansion of benthic scavenger populations as a response to discards is weak. The annual amount of carrion produced by fishing activities in the North Sea is estimated to account for up to $10 \%$ of the overall annual food consumption of scavengers (Lindeboom \& de Groot 1998, Groenewold \& Fonds 2000).

Although the frequent receipt of carrion has the potential to affect community structure, there is an emerging consensus that while fishing temporarily augments the diet of benthic scavengers, it is unlikely to constitute its major part (Bergmann et al. 2002a). When utilising discards, scavenging benthic invertebrates rely on chance occurrence of food falls within the range of their relatively small sensory and ambulatory capabilities (Sainte-Marie \& Hargrave 1987, Nickell \& Moore 1992, Ramsey et al. 1997). Therefore, only in intensively fished areas, offering repeat encounters with discards during important periods of food demand, are positive effects on benthic scavenger populations considered possible (Groenewold \& Fonds 2000).

The NE Atlantic Nephrops norvegicus (hereafter Nephrops) trawl fisheries are ranked as having the fifth highest discard ratio in the world (Alverson 1997). The Nephrops trawl fishery off the NE coast of England, adjacent to the Farne (Farn) Deep area, is intensively fished and has an overall discard rate of $57 \%$ (Catchpole et al. 2005). During the 2001 to 2002 season (September 2001 to April 2002), there was an estimated total of 8545 tonnes (t) of fish and Nephrops caught by vessels in this fishery, of which 4890 t were discarded (including Nephrops heads-the by-product of Nephrops processing) (Catchpole et al. 2005).

The principal port for this fishery is North Shields, which receives $>1000$ t of Nephrops norvegicus landings annually, more than half the total for this fishery. The ports of Blyth, Amble and Hartlepool receive most of the remainder (Lee 2001, 2002). The fishing grounds, on which more than 80 vessels can be working at one time (Catchpole et al. 2005), are relatively small (75 km from north to south and $>58 \mathrm{~km}$ from east to west). Given the intensity of exploitation, the small total area and the large quantities of discards, this fishery may meet the criteria set out by Fonds \& Groenewold (2000).

The aim of this study was to determine whether the quantity and quality of discarded material from the English Nephrops fishery is such that it has a positive effect on marine scavenger populations. The main practical difficulty in obtaining data on the effect of discarding on community structure is the scarcity of any unfished control sites to satisfy the requirements of scientific testing (Wieczorek et al. 1999). An alternative approach is to use bioenergetic models to determine the potential contribution of discards to identified scavengers (Lindeboom \& de Groot 1998, Groenewold $\&$ Fonds 2000). Therefore, a bioenergetic model was developed for the English Nephrops fishery to evaluate the importance of discards to identified marine scavenging species.

\section{MATERIALS AND METHODS}

We conducted 7 field studies to identify the discard scavenging species and estimate their densities. Onboard discard simulation experiments combined with data from commercial vessels provided estimates of the partitioning of discards between aerial and marine scavenging species and the spatial distribution of discarding. Using published values for the energy requirements of the identified scavengers, a bioenergetic model was devised from the literature to evaluate the potential importance of discards as a food source.

Partitioning of discards between aerial and marine scavengers. The proportion of discards utilised by seabirds was estimated from discard experiments on 5 November 2001, and 20 March and 16 April 2002. Three $1 \mathrm{~h}$ trawls were conducted from the RV 'Bernicia' using a commercial Nephrops trawl $(70 \mathrm{~mm}$ mesh codend) on the fishing grounds. The catch was separated by species and then into the size ranges discarded by commercial vessels, and 9 of the species caught (see Table 1), which constitute over $95 \%$ of the total discarded material (Catchpole et al. 2005), were selected for the experiments. 
Whole Nephrops of the size normally discarded and the heads of Nephrops normally tailed (i.e. discarded) were thrown into the sea to simulate commercial tailing practices (Catchpole et al. 2005). Simultaneously, 5 fish of the same species or 5 Nephrops were thrown from the stern of RV 'Bernica' in the area fished by commercial vessels, while 2 observers recorded their fate, including (if taken by a bird) the species of seabird. The method of multiple releases was chosen to best replicate commercial discard practices (Stratoutakis 1999); 5 items could be reliably tracked on repeat experiments.

The estimated quantities of discards in the 2001 to 2002 season were taken from Catchpole et al. (2005). The energy content of the discards of each species were calculated (Garthe et al. 1996, Hansson et al. 1996, Lawson et al. 1998, Ricciardi \& Bourtget 1998 and Pedersen \& Hislop 2001). The discard quantity taken by seabirds and its energy content were estimated from the mean proportion of each discarded species taken by seabirds. The remaining material gave an estimate of the quantity and energy content of discards available to benthic and demersal scavengers. The discard mortality rate for Nephrops and fishes was assumed to be 100\% (Evans et al. 1994).

Spatial distribution of discards. Data from commercial vessels working from North Shields were collected during a catch and discard sampling programme in 2001 to 2002 (see below). The positions of trawls sampled on board commercial vessels, the time taken to sort the catch, and the speeds of commercial vessels while returning to North Shields were recorded. The distances travelled back to North Shields by commercial vessels (great-circle method) and the proportions of the return journeys spent over the fishing grounds were calculated using the mean vessel speed.

A model for the spatial distribution of discards was formulated based on the following assumptions:

- The proportion of time spent sorting in each area (on the fishing grounds, between the fishing grounds and ports and at the ports) was equal to the proportion of discarding

- Vessels from other ports spent the same time discarding in each area as those from North Shields. This assumption was based on the orientation of fishing grounds, which run parallel to the coast on which these ports are situated

- The proportion of official landings at each port (Lee 2001, 2002) was equal to the proportion of discarding occurring at each port

- The proportion of discards taken by seabirds was constant throughout the season. Large numbers of seabirds (predominantly herring gulls) were observed feeding on discards from commercial vessels throughout the discard sampling programme
- The proportion of discards taken by seabirds was the same in all areas - seabirds were observed feeding on discards at the port and while commercial vessels sailed back to port. Up to 1000 herring gulls were seen in Blyth South harbour and up to 3500 herring gulls in the Tyne Estuary around North Shields in 2001 (Turner 2000, 2001). The aggregation of gulls at these ports is attributed to the availability of discards from fishing vessels (Turner 2001).

Identifying benthic and demersal scavengers. We conducted 2 trapping experiments, one to identify species utilising discards on the fishing grounds, the other to identify species utilising discards at North Shields fish quay. Baited traps of different designs with variable selection properties were used with the aim of catching the full range of scavenging species (Lindeboom and de Groot 1998).

Fish quay traps. We deployed 3 standard Nephrops creels and 3 funnel traps separately from the fish quay wall at North Shields or from fishing vessels moored to the quay. The traps were baited with Nephrops heads or whiting. The creels were deployed for 15 or $30 \mathrm{~min}$, and the funnel traps for 1 or $2 \mathrm{~h}$. Multiple deployments were made on each of $8 \mathrm{~d}$ during the period 15 October to 25 November 2002 between 10:00 and 16:00 h. On retrieval the species caught were identified, measured and weighed.

Fishing ground traps. Trapping experiments had not previously been attempted on the English Nephrops fishing grounds. We connected 3 types of trap into 1 fleet consisting of 7 Nephrops creels (35 mm mesh size; $70 \mathrm{~mm}$ eye diameter), 6 cylindrical crayfish traps (10 mm wire mesh; $45 \mathrm{~mm}$ whole diameter), and 6 funnel traps (25 mm whole diameter) (Bergmann et al. 2002a). A sequence of 1 of each trap type was repeated along the fleet, the traps were spaced $5 \mathrm{~m}$ apart. Each trap was weighted and contained a fine mesh (10 mm) bait bag holding whole whiting Melangius merlangus, Nephrops heads and Nephrops of a size commonly discarded-an estimated $86 \%$ of discarded material in this fishery is made up of these 2 species (Catchpole et al. 2005).

We made 5 deployments of the traps between September 2004 and April 2005 at different locations on the fishing grounds in depths of 52 to $90 \mathrm{~m}$. The traps could only be left for $2 \mathrm{~h}$ owing to the activity of commercial vessels and the depth at which the traps were deployed. This was considered enough time to attract benthic discard scavengers as has been shown in previous studies (Ramsey et al. 1997, Bergmann et al. 2002a). On retrieval, trapped scavengers were identified, measured and weighed in the laboratory. Bait bags were examined and any evidence of feeding noted.

Stomach analysis. Catch efficiencies for demersal fishes in traps similar to those used in this study can be 
low (Groenewold \& Fonds 2000). Therefore, to increase the chance of identifying discard scavenging demersal fishes, stomach samples were examined for evidence that demersal fishes feed on discarded material (Wieczorek et al. 1999, ICES 2000).

We sampled 6 trawls from 3 commercial vessels during the 2002 to 2003 fishing season. Sample collection took place during periods of high fishing activity to increase the likelihood of identifying discard scavenging fish species. For fish selected by fishermen for landing, total lengths were measured and the stomachs removed while on board. Samples of fishes to be discarded were returned to the laboratory whole. All samples were frozen prior to analysis.

In the laboratory, stomachs and whole fish were defrosted, the lengths of whole fish measured and the stomachs removed. The stomachs were classified as either empty or having food present. The stomachs were weighed and prey items identified to the lowest taxonomic group possible. Any prey species also discarded by commercial vessels (Catchpole et al. 2005) were measured. The percentage composition of diets, by numbers of prey, were calculated for each fish species and the importance of discards as a food source evaluated. In this analyses it was only possible to state that food items also found in the discard fraction and occurring in the size ranges discarded could potentially have come from discarded catches.

Bioenergetic model for marine scavengers. A bioenergetic model was developed for marine species identified as discard scavengers on the fishing grounds; the fishing grounds receive an estimated $83 \%$ of all discarded material. The extent that discards contribute to sustaining populations of identified marine scavengers was then assessed. The model required knowledge of: (1) scavenger densities, (2) energy requirements of scavengers and (3) total energy requirements of scavenger populations relative to the energy content of the available discards.

Estimates of marine scavenger densities: These were calculated from 4 sources: (1) Sampled commercial Nephrops trawls, (2) Nephrops trawls conducted on the RV 'Bernicia', (3) fine-mesh trawls conducted on the RV 'Bernicia', (4) trapping experiments (Myxine glutinosa only).

For (1) to (3), the numbers caught per trawl were divided by trawled area to provide catch numbers per area. The dimensions of the nets and warp separation were used to calculate the doorspread $(D S)$ and wingspread (WS) (Eqs. 1 to 3) for all trawls. Skippers provided trawl specifications for commercial trawls, measurements of trawls used on the RV 'Bernicia' were taken from trawl schematics. Warp separation was measured during trawling.

$$
\begin{aligned}
& D S=(a b 1.12) \\
& W S=2[\theta(e+f)] \\
& \theta=\frac{0.5 D S}{(c+d+e+f)}
\end{aligned}
$$

where $a=$ length of warp out; $b=$ warp separation at 1 fathom; $c=$ bridle length; $d=$ sweep length, $e=$ half ground-rope length; $f=$ length of net from mid groundrope to codend.

Trawl duration and trawling speeds were recorded allowing the calculation of estimated wingswept areas and the number of each species $\mathrm{km}^{-2}$ caught for each trawl. Using otter trawls to sample fishes and benthos (Sarda et al. 1994, Kallianiotis et al. 2000) was the best available method, but assumed high catch efficiencies for the identified discard scavengers. The 3 trawl sampling methods used to determine catch numbers per trawl and the baited-trap method used for density estimates were: (1) Sampling on commercial fishing vessels working from North Shields on the Nephrops fishing grounds in the 2001 to 2002 fishing season (Catchpole et al. 2005), whereby 2 baskets of unsorted catch (each 20 to $30 \mathrm{~kg}$ ) were sorted into constituent species and measured; 76 trawls were sampled; the samples were raised to total catch numbers per trawl using landings-based raising factors (for full details of sampling method see Catchpole et al. 2005). Methods (2) and (3): Trawls conducted on board the RV 'Bernicia' using either (2) a Nephrops trawl (codend mesh size $70 \mathrm{~mm}$ ) towed for 1 to $1.67 \mathrm{~h}$ on the Nephrops fishing grounds during the fishing season in 2001 to 2002, or (3) a fine-mesh prawn trawl (codend mesh size $10 \mathrm{~mm}$ ) towed for 0.33 to $0.4 \mathrm{~h}$ on the Nephrops fishing grounds during the fishing season in 2002 to 2004. All catches using Trawl Methods 2 and 3 were sorted into constituent species, measured and the catch numbers totalled. (4) The catch rates of the hagfish Myxine glutinosa in baited traps allowed density estimates, using the method of Stanley et al. (1985), Sainte-Marie \& Hargrave (1987), Martini \& Heiser (1997) and Collins et al. (2002). The method assumed that all hagfish within the area of an odour plume from a bait source are attracted to that source. Current velocity was used to predict the area of the odour plume. Estimated current velocities were provided by the Management Unit of the North Sea Mathematical Models (MUMM) (Anonymous 2005) for the location, time and duration of the trap deployments (at $10 \mathrm{~min}$ intervals). Hagfish were attracted to all traps but retained mostly in funnel traps (see 'Results'). The number of hagfish caught in funnel traps in each deployment was raised by a factor of 3.167 under the assumption that the number of hagfish retained in the funnel traps were also attracted to the other trap types. 
The width of the odour plume $(W)$ was calculated for 1 point source of bait odour. The area of the plume $(A)$ was assumed to be an ellipse $(A=\pi \mathrm{L} W / 4)$ (Stanley et al. 1985). The length of the odour plume $(L)$ was calculated from the mean current velocity multiplied by the time of deployment and added to the length of the fleet of traps $(90 \mathrm{~m})$. The area of the odour plume to which the hagfish were attracted (area of attraction) (Collins et al. 2002) was calculated using a maximum swimming speed for hagfish of $1 \mathrm{~m} \mathrm{~s}^{-1}$ (Foss 1968).

The sampling method (1 to 4 ) that provided the highest mean density estimate for each discard scavenger species was considered the best estimate. Estimated scavenger numbers $\mathrm{km}^{-2}$ were multiplied by total area of the fishing grounds to estimate population sizes. The area of the fishing grounds was calculated from Symonds (1972), and corroborated with information from chart-plotters used by skippers of commercial vessels.

Energy requirements of scavenging species: Energy requirements were calculated from either weight specific oxygen consumption rates, energy budgets from feeding experiments or daily food consumption rates, depending on what published data were available. Oxygen consumption was converted to energy equivalents (Gnaiger \& Bitterlich 1984), and the wet weights of food consumed were converted to energy equivalents. Samples of discard scavengers were taken from RV 'Bernicia' trawl catches and weighed. Weight specific daily energy requirements, mean energy requirements per weight, and mean weights were calculated for each scavenging species.

Total energy requirements of scavenger populations relative to energy content of available discards: Scavenger population numbers were multiplied by mean weights and then by mean energy requirements per weight to calculate the total energy requirements of discard scavenging species. The energy content of the discards as a percentage of the total energy demand of the discard scavengers provided a percentage contribution that discards could make to the energy demand of the scavenger assemblage.

In addition to the bioenergetic model, the potential number of identified seabird and North Shields fish quay scavengers that could be supported by the discards available to them was calculated. Mean energy demands were calculated by multiplying published energy requirements by published mean weights for seabird scavengers and by mean weights derived from trap samples for fish quay marine scavengers.
The proportion of discards utilized by each scavenging species was assumed to be equal to the proportions observed in discard experiments for seabirds and in trap catch compositions for fish quay scavengers. The total energy content of available discards divided by the energy demand of the discard scavengers for the period of the fishing season provided the numbers of seabird and fish quay scavenging species that could be supported by the discards.

\section{RESULTS}

\section{Partitioning of discards between aerial and marine scavengers}

Herring gulls Larus argentatus were the dominant seabird scavenger (Table 1). Northern gannets Morus bassanus were the only other seabird species observed utilizing discards during discard experiments. Herring gulls took most of the discarded roundfishes and gannets took more flatfishes than herring gulls (Table 1).

Observations from on board commercial vessels showed that great black-backed gulls Larus marinus and great skuas Stercorarius skua also occasionally utilized discarded fishes (but were not included in the bioenergetic model), while gannets were seen diving for fishes released from the codend during the hauling process. On board commercial vessels, the discards were released at intervals, several $\mathrm{kg}$ at a time.

Seabirds took an estimated $57 \%$ of all discarded material (Table 2). The energy content of this fraction was $11.6 \times 10^{9} \mathrm{~kJ} ; 83 \%$ was whiting. Discards taken by seabirds could have potentially supported $31600 \mathrm{Her}-$ ring gulls and 273 gannets during the 2001 to 2002 fishing season (assuming that seabirds fed exclusively on discards): field metabolic rates and assimilation rate taken from Birt-Friesen et al. (1989), Pons \& Migot (1995), Garthe et al. (1996) and Hunt et al. (2000).

Table 1. Mean percentage of discarded fishes and Nephrops norvegicus taken by herring gulls Larus argentatus and gannets Morus bassanus in discard experiments. n: number of discard simulations of 5 fishes or N. norvegicus

\begin{tabular}{|c|c|c|c|c|}
\hline Discarded species & $\mathrm{n}$ & $\begin{array}{l}\text { Herring } \\
\text { gull }\end{array}$ & Gannet & $\begin{array}{l}\text { Mean all } \\
\text { seabirds }\end{array}$ \\
\hline Nephrops norvegicus & 52 & 16 & 0 & 16 \\
\hline Whiting Melangius merlangus & 50 & 83 & 2 & 85 \\
\hline Haddock Melanogrammus aeglefinus & 17 & 75 & 0 & 75 \\
\hline Four-beard rockling Enchelyopus cimbrius & 24 & 77 & 0 & 77 \\
\hline Long-rough dab Hippoglossoides platessoides & 28 & 3 & 15 & 18 \\
\hline Common dab Limanda limanda & 24 & 4 & 19 & 23 \\
\hline Cod Gadus morhua & 6 & 53 & 0 & 53 \\
\hline Lemon sole Miscrostomus kitt & & & & \\
\hline Plaice Pleuronectes platessa & 8 & 0 & 0 & 0 \\
\hline
\end{tabular}


The remaining discards, an estimated $2040 \mathrm{t}$ with an energy content of $8.6 \times 10^{9} \mathrm{~kJ}$, were available to benthic and demersal scavengers; $59 \%$ was Nephrops (including heads) and $22 \%$ was whiting.

\section{Spatial distribution of discards}

Fishing vessels returned to port after each day of fishing, and generally conducted 2 tows $\mathrm{d}^{-1}$ (Catchpole

Table 2. Estimated spatial distribution of discards (in tonnes, t) from the English Nephrops norvegicus fishery taken by seabird (aerial) scavengers and available to benthic and demersal (marine) scavengers in 2001 to 2002 fishing season

\begin{tabular}{|c|c|c|c|c|}
\hline \multirow[t]{2}{*}{ Area } & \multicolumn{2}{|c|}{ Aerial scavengers } & \multicolumn{2}{|c|}{ Marine scavengers } \\
\hline & $\mathrm{t}$ & $\begin{array}{l}\text { Energy } \\
\left(10^{6} \mathrm{~kJ}\right)\end{array}$ & $\mathrm{t}$ & $\begin{array}{l}\text { Energy } \\
\left(10^{6} \mathrm{~kJ}\right)\end{array}$ \\
\hline Fishing grounds & 2273 & 9663 & 1692 & 6683 \\
\hline Between fishing grounds and ports & 293 & 1244 & 218 & 861 \\
\hline At ports: North Shields & 87 & 370 & 65 & 256 \\
\hline Blyth & 35 & 148 & 26 & 102 \\
\hline Amble & 31 & 133 & 23 & 92 \\
\hline Hartlepool & 21 & 89 & 16 & 61 \\
\hline Total & 2740 & 11647 & 2040 & 8055 \\
\hline
\end{tabular}

Table 3. Total numbers (by species) caught in Nephrops creels and funnel traps baited with fishery discards at North Shields fish quay

\begin{tabular}{|cllr|}
\hline Trap type & Species & Common name & $\begin{array}{r}\text { Total } \\
\text { catch }\end{array}$ \\
\hline $\begin{array}{c}\text { Nephrops creel } \\
(\mathrm{n}=219)\end{array}$ & Carcinus maenas & Common shore crab & 2175 \\
& Lithodes maja & Spider crab & 1 \\
& Cancer pagurus & Edible crab & 2 \\
& Pollachius virens & Coley & 1 \\
& Myoxocephalus scorpius & Scorpion fish & 1 \\
& Gaidropsarus mediterraneus & Five-beard rockling & 2 \\
Funnel trap & Zoarces viviparus & Eelpout & 2 \\
$(\mathrm{n}=18)$ & Zoarces viviparus & Eelpout & 2 \\
\hline
\end{tabular}

Table 4. Total numbers (by species) caught in Nephrops creels, crayfish traps and funnel traps baited with fishery discards and deployed on English $N$. norvegicus fishing grounds

\begin{tabular}{|c|c|c|c|c|}
\hline \multirow{2}{*}{ Species } & \multirow{2}{*}{ Common name } & \multicolumn{3}{|c|}{ Trap type } \\
\hline & & $\begin{array}{l}\text { Nephrops } \\
(\mathrm{n}=35)\end{array}$ & $\begin{array}{l}\text { Crayfish } \\
(\mathrm{n}=30)\end{array}$ & $\begin{array}{l}\text { Funnel } \\
(\mathrm{n}=30)\end{array}$ \\
\hline Myxine glutinosa & Hagfish & - & 5 & 713 \\
\hline Pagurus bernhardus & Hermit crab & 16 & - & - \\
\hline Neptunea antiqua & Red whelk & 2 & 1 & - \\
\hline Buccinum undatum & Common whelk & - & 1 & - \\
\hline Liocarcinus depurator & Swimming crab & 4 & 1 & - \\
\hline Asterias rubens & Starfish & 4 & - & - \\
\hline
\end{tabular}

et al. 2005). The mean distance back to North Shields the position of hauling the second tow was $38 \mathrm{~km}$, fishing grounds while the second tow was in pro The total area of the fishing grounds was estimated at $2504 \mathrm{~km}^{2}$. With an observed mean speed on returning to port of 9 knots, an estimated $83 \%$ of discarding took place over the fishing grounds, $11 \%$ between the fishing grounds and port, and $6 \%$ in the ports (Table 2).

\section{Fish quay scavengers}

Carcinus maenas was the most frequently caught scavenger at North Shields fish quay (Table 3). Nephrops creels caught up to 64 C. maenas in $15 \mathrm{~min}$. Also observed feeding on discarded fishes at the fish quay were grey seals Halichoerus grypus, kittiwakes Rissa tridactyla and herring gulls.

Energy requirements of scavengers at the fish quay were available only for Carcinus maenas and Cancer pagurus. The discards deposited at the fish quay and available to marine scavengers could have potentially supported 337000 Carcinus maenas and 310 Cancer pagurus during the fishing season (estimated from oxygen consumption rates; Hamilton \& Houlihan 1992, Watt et al. 1999).

\section{Fishing ground traps}

Catches of scavengers on the fishing grounds were dominated by the hagfish Myxine glutinosa (Table 4). All funnel traps caught hagfish, with up to 85 per trap. All benthic invertebrates were recovered from the other trap designs. The slime exuded by hagfish (Martini 1998) was also found on these other trap types, showing that although not retained, hagfish had entered and escaped from these traps. Examination of the bait bags showed that bait utilization was rapid, with only skeletal remains left after $2 \mathrm{~h}$ in all traps in 4 of the 5 deployments. 


\section{Stomach analysis}

There were 5 to 14 commercial vessels trawling within a 3 nautical mile radius of the vessels from which stomach samples were taken. The stomachs of 10 fish species were examined; 614 stomachs were collected and 1213 prey items were identified (Table 5). Bivalves were the most common prey for plaice Pleuronectes platessa, and polycheates for lemon sole Microstomus kitt, crustaceans dominated the diets of all other fish species. Pagurus bernhardus was the most numerous prey item for common dabs Limanda limanda and Liocarcinus depurator for starry rays Raja radiata. Euphausids were the most common prey for whiting Merlangius merlangus, and coridean shrimp species for cod Gadus morhua, haddock Melanogrammus aeglefinus, long-rough dab Hippoglossoides platessoides, four-beard rockling Enchelyopus cimbrius, tub gurnard Trigla lucerna and cuckoo ray Raja neavus.

Nephrops norvegicus, Liocarcinus depurator, Pagurus bernhardus, Pandalus montagui, Crangon crangon and Aphrodita aculeata were prey species also found in the discard component of commercial catches. It cannot be determined whether these prey items originated from discards. Demersal fish were considered not to be major consumers of discards on the fishing grounds based on:

- The rapid arrival of discarded material at the seafloor. With an estimated mean depth on the fishing grounds of $75 \mathrm{~m}$ and a sinking speed for Nephrops heads at $10.3 \mathrm{~cm} \mathrm{~s}^{-1}$ (Bergmann et al. 2002a), most discards not utilized by seabirds would arrive on the seabed in $12 \mathrm{~min}$

- The rapid utilization of discards by benthic scavengers in baited traps (see last subsection)

- The absence of demersal fish from baited traps (which caught demersal fish at the fish quay)

- The absence of Nephrops heads (which make up $53 \%$ of discarded material available to benthic and demersal scavengers) from stomach samples

- The size range of whole Nephrops in stomach samples. Fishermen retain Nephrops of $>32$ mm carapace length (CL) whole; those $>21 \mathrm{~mm}$ CL are tailed, and those $<21 \mathrm{~mm}$ CL are discarded whole; commercial vessels do not catch Nephrops <13 mm CL (Catchpole et al. 2002). Nephrops were most abundant in the diets of haddock and cod; however, $>60 \%$ of Nephrops consumed by these species were of a size that indicated that they could not have originated from discards under these criteria

Table 5. Stomach contents (number of prey items) of 11 fish species collected from commercial vessels on the English Nephrops norvegicus fishing grounds. Values in parentheses: \% empty stomachs. Specific names of fishes given in Table 1

\begin{tabular}{|c|c|c|c|c|c|c|c|c|c|c|c|}
\hline Prey & $n: \begin{array}{l}171 \\
(47)\end{array}$ & $\begin{array}{c}144 \\
(7)\end{array}$ & $\begin{array}{c}\text { Haddock } \\
108\end{array}$ & $\begin{array}{c}\text { Long- } \\
\text { rough } \\
\text { dab } \\
60 \\
(45)\end{array}$ & $\begin{array}{c}\text { Four- } \\
\text { beard } \\
\text { rockling } \\
53 \\
(26)\end{array}$ & $\begin{array}{c}\text { Com- } \\
\text { mon } \\
\text { dab } \\
24 \\
(67)\end{array}$ & $\begin{array}{c}\text { Tub } \\
\text { gurnard } \\
17 \\
(65)\end{array}$ & $\begin{array}{c}\text { Lemon } \\
\text { sole }\end{array}$ & $\begin{array}{c}13 \\
(92)\end{array}$ & $\begin{array}{c}\text { Cuckoo } \\
\text { ray }\end{array}$ & $\begin{array}{c}\text { Starry } \\
\text { ray } \\
\\
6 \\
(67)\end{array}$ \\
\hline Nephrops norvegicus & 0 & 17 & 14 & 0 & 2 & 8 & 3 & 0 & 0 & 0 & 0 \\
\hline Pandalus montagui & 3 & 20 & 6 & 14 & 2 & 0 & 3 & 0 & 0 & 0 & 0 \\
\hline Crangon crangon & 11 & 52 & 8 & 31 & 19 & 0 & 88 & 0 & 0 & 100 & 0 \\
\hline Calocaris macandreae & 6 & 2 & 30 & 2 & 18 & 8 & 3 & 0 & 0 & 0 & 0 \\
\hline Iphinoe trispinosa & 0 & 0 & 0 & 0 & 14 & 0 & 0 & 0 & 0 & 0 & 6 \\
\hline Pagurus bernhardus & 0 & 1 & 0 & 0 & 2 & 58 & 0 & 14 & 0 & 0 & 0 \\
\hline Liocarcinus depurator & 0 & 2 & 1 & 0 & 0 & 0 & 3 & 0 & 0 & 0 & 82 \\
\hline Brachynotus sexdentatus & 0 & 0 & 0 & 0 & 0 & 0 & 0 & 0 & 0 & 0 & 6 \\
\hline Infraorder Brachyura & 0 & 0 & 2 & 10 & 7 & 0 & 0 & 0 & 0 & 0 & 0 \\
\hline Order Euphausiacea & 70 & 0 & 9 & 8 & 2 & 0 & 0 & 0 & 0 & 0 & 0 \\
\hline Order Mysidacea & 1 & 0 & 0 & 0 & 0 & 0 & 0 & 0 & 0 & 0 & 0 \\
\hline Order Amphipoda & 0 & 0 & 0 & 2 & 19 & 0 & 3 & 0 & 0 & 0 & 0 \\
\hline Superfamily Penaeoidea & 4 & 0 & 0 & 20 & 7 & 0 & 0 & 0 & 0 & 0 & 0 \\
\hline Phylum Crustacea & 0 & 0 & 2 & 8 & 5 & 25 & 0 & 0 & 0 & 0 & 0 \\
\hline Molva molva & 0 & 0 & 0 & 2 & 0 & 0 & 0 & 0 & 0 & 0 & 0 \\
\hline Gadoid fish & 1 & 2 & 0 & 0 & 0 & 0 & 0 & 0 & 0 & 0 & 0 \\
\hline Sepiola atlantica & 0 & 0 & 0 & 0 & 0 & 0 & 0 & 0 & 0 & 0 & 0 \\
\hline Class Cephalopoda & 0 & 0 & 0 & 0 & 0 & 0 & 0 & 0 & 0 & 0 & 6 \\
\hline Class Bivalvia & 0 & 0 & 20 & 0 & 0 & 0 & 0 & 14 & 100 & 0 & 0 \\
\hline Aphrodita aculeata & 0 & 1 & 2 & 0 & 0 & 0 & 0 & 0 & 0 & 0 & 0 \\
\hline Class Polychaeta & 1 & 0 & 0 & 2 & 0 & 0 & 0 & 57 & 0 & 0 & 0 \\
\hline Class Ophiuroidea & 0 & 0 & 2 & 0 & 0 & 0 & 0 & 0 & 0 & 0 & 0 \\
\hline Amphiura spp. & 0 & 0 & 4 & 0 & 0 & 0 & 0 & 0 & 0 & 0 & 0 \\
\hline Unidentifiable & 1 & 0 & 2 & 0 & 4 & 0 & 0 & 14 & 0 & 0 & 0 \\
\hline
\end{tabular}


- The catch efficiency of commercial trawls (compared with fine mesh trawls) of prey species also discarded by commercial vessels was low $(<2 \%)$; with the exception of Liocarcinus depurator.

Demersal fishes were not, therefore, included in the bioenergetic model.

\section{Bioenergetic model}

Fine mesh trawls (mean wingswept area $0.01 \pm$ $0.0002 \mathrm{~km}^{2} ; \mathrm{n}=12$ ), provided the highest mean density estimates for Liocarcinus depurator, Asterias rubens and Pagurus bernhardus (estimates were 3, 3 and 35 times that of estimates derived from commercial trawls). Nephrops trawls conducted on board the RV 'Bernicia' (mean wingswept area $0.1 \pm 0.005 \mathrm{~km}^{2}$; $\mathrm{n}=10$ ) provided the highest mean density estimates for Buccinum undatum and Neptunea antiqua (Table 6). The highest density estimates for Myxine glutinosa were numbers per area of attraction to baited traps.

The mean bottom current velocity was $0.13 \mathrm{~m} \mathrm{~s}^{-1}$ $(0.055$ to $0.274 \mathrm{~m})$ during trap deployments and the estimated mean area of attraction was $24032 \mathrm{~m}^{2}$ (14 450 to $27750 \mathrm{~m}^{2}$ ). The estimated energy requirement for hagfish was equated to weight-specific oxygen consumption $\left(\mu \mathrm{mol} \mathrm{O} \mathrm{g}^{-1} \mathrm{~h}^{-1}=86.8\right.$ weight $^{-0.826}$; calculated from Lesser et al. 1996). Hagfish were the most numerous scavengers, and made up $79 \%$ by weight of all identified benthic scavengers on the fishing grounds. The estimated energy required by the hagfish population made up $82 \%$ of the energy requirements of the total discard scavenger assemblage (Table 6).

Neptunea antiqua made up the next largest component of scavengers, $16 \%$ of the total weight of the discard scavenger assemblage. Data on the energy requirements of the Buccinum undatum (consumption

Table 6. Estimated mean density, individual weights, energy requirements and population energy requirements for one fishing season of the identified benthic discard scavengers on the English Nephrops norvegicus fishing grounds

\begin{tabular}{|lrrrrr|}
\hline Scavenger species & $\begin{array}{c}\text { Density } \\
\left(\text { no. } \mathrm{km}^{-2}\right)\end{array}$ & $\begin{array}{c}\text { Ind. } \\
\mathrm{wt} \\
(\mathrm{g})\end{array}$ & $\begin{array}{c}\text { Population } \\
\text { biomass } \\
(\mathrm{t})\end{array}$ & $\begin{array}{c}\text { Energy requirements } \\
\text { Daily } \\
\left(\mathrm{J} \mathrm{g}^{-1} \mathrm{~d}^{-1}\right)\end{array}$ & $\begin{array}{c}\text { Season } \\
(\mathrm{kJ} \mathrm{10})\end{array}$ \\
\hline Buccinum undatum & 43 & 97 & 56 & 11 & 119 \\
Neptunea antiqua & 643 & 144 & 56 & 232 & 2619 \\
Liocarcinus depurator & 416 & 8 & 48 & 9 & 85 \\
Pagurus bernhardus & 3459 & 5 & 37 & 48 & 354 \\
Asterias rubens & 199 & 14 & 52 & 7 & 72 \\
Myxine glutinosa & 16465 & 28 & 63 & 1156 & 14648 \\
Total & & & & 1462 & 17896 \\
Total energy content of available discards & & & & 6683 \\
\hline
\end{tabular}

rate of gadoids in $\mathrm{J} \mathrm{g}^{-1} \mathrm{~h}^{-1}$; from Evans et al. 1996) were also used for $N$. antiqua because no other data were available. The assumption that the energy requirements were comparable was based on the 2 species being closely related, their similar diets, comparable sizes, travelling speeds and biology (Pearce 1967, Taylor 1978, Power et al. 2002).

Pagurus bernhardus was the second most abundant benthic discard scavenger (energy requirement from oxygen consumption rates: Bridges \& Brand 1980). Asterias rubens and Liocarcinus depurator made up the smallest component of the scavenger assemblage. The energy demand of $A$. rubens was based on fish consumption rates (Lindeboom \& de Groot 1998, where $1 \mathrm{~g}$ fish $=4 \mathrm{~kJ}$ ), and for $L$. depurator on weightspecific oxygen consumption rates $\left(\mu \mathrm{O}_{2}\right.$ ind. $\mathrm{h}^{-1}=$ 436weight ${ }^{0.367}$; from Johnson \& Rees 1988).

The identified marine discard scavengers on the English Nephrops fishing grounds required an estimated $17.9 \times 10^{9} \mathrm{~kJ}$ of energy for the duration of 1 fishing season $(201 \mathrm{~d})$. The energy content of discards available to benthic scavengers could provide $37 \%$ of their total energy requirements during the fishing season or $21 \%$ of their annual energy requirement (Table 6).

\section{DISCUSSION}

The bioenergetic model indicated that the energy available from discards could potentially provide the identified benthic discard scavengers on the fishing grounds with $37 \%$ of their energetic requirements during the fishing season. The model made 4 main assumptions:

Assumption 1: the proportion of discard material utilized by seabirds was constant throughout the season, although many species are known to display seasonal fluctuations in distribution (Camphuysen et al. 1995). Under this assumption seabirds utilized an estimated $57 \%$ of the discarded material in the English Nephrops fishery.

The dominant seabird scavengers during simulated discarding were herring gulls Larus argentatus followed by northern gannets Morus bassanus. This was also consistent with observations made during the commercial vessel sampling programme. The Herring gull population is known to be elevated consistently at North Shields and Blyth from September to March. At this time, Herring gulls from Scotland and Scandinavia join the resident popula- 
tion (Turner 2000) with up to 140000 herring gulls overwintering in NE England (Goodwin \& Goodwin 2005, available at homepage.mac.com/wings_4d/ bonc/bonc_pages/bonc_accounts/species_accounts/ Herring\%20Gull/HRGU.html).

There are no equivalent data available on temporal changes in the Northern Gannet population during the season, and so less confidence in the proportion of discards taken by them. However, because Northern gannets were less prolific scavengers than Herring gulls during discard simulations, any change in their numbers (not perceived during the sampling programme) was considered to have only a small effect on the relative proportion of discards utilized by aerial and marine scavengers.

During the sampling programme it was also notable that the amount of discard material ejected at any one time from commercial vessels was larger than in experimental simulations. Discarding material in smaller amounts can increase the scavenging success of seabirds (Garthe \& Hueppop 1998). Therefore, the proportion of material consumed by seabirds under commercial conditions may be less than observed in our study, and consequently the amount of discards available to the bentho-demersal assemblage could be underestimated. The amount of discards reaching the seabed has been estimated at 67 to $80 \%$ (Lindeboom \& de Groot 1998, Wieczorek et al. 1999); however, this value is dependent on the composition of the catch and will vary between fisheries. Estimates by Camphuysen et al. (1995) that seabirds in the North Sea consume $80 \%$ of roundfishes, $20 \%$ of flatfishes and $10 \%$ of invertebrates are consistent with the results presented here.

Assumption 2: model derived bottom current velocity estimates were assumed to be accurate. Density estimates of Myxine glutinosa required current velocities, which could not be measured in situ during trap deployments and were provided by the Management Unit of the North Sea Mathematical Models.

Assumption 3: the trawl samples were assumed to provide accurate scavenger density estimates. There is no single standard sampling gear for benthos investigations, and otter trawls can have lower catch efficiencies than other methods (Rumohr 1999). Therefore, trawl derived scavenger densities may be underestimated.

Although no direct comparisons can be made, density estimates for the species identified as benthic scavengers were lower in this study than those for a similar mud habitat in the Irish Sea, where estimates were derived from beam trawls. Differences in density estimates between these 2 sites range from 2.8 times lower in the English Nephrops fishery for Pagurus bernhardus to 123 times lower for Liocarcinus depurator (Ramsey et al. 1997).
Densities of the identified benthic scavenger species do show considerable spatial variability. In the Clyde Sea Nephrops fishery, in commercial trawls, invertebrates can account for up to $90 \%$ of the discard material, with up to $73 \%$ of these being echinoderms, mostly Asterias rubens (Bergmann \& Moore 2001). Similarly, Liocarcinus depurator can account for up to $51 \%$ of the total discard biomass (Bergmann et al. 2001).

The English Nephrops fishery is recognized as an area of low invertebrate abundance (Bergmann et al. 2002). However, it is acknowledged that the lower density estimates in this study allow for the potential contribution of discards to the energy requirements of benthic scavengers to be higher than in other studies.

Assumption 4: demersal fishes were assumed not to utilize discarded material. There was no direct evidence that demersal fishes utilize discards in this fishery; however, the scale of the trapping programme (190 h of baited trap deployment) and stomach contents analysis may have been insufficient to identify demersal fish scavengers. Fish catches did form 3 and $5 \%$ of baited trap catches in the southern North Sea (excluding amphipods) and the Clyde Sea (Groenewold \& Fonds 2000, Bergmann et al. 2002). In the southern North Sea it was estimated that demersal fishes could account for $18 \%$ of the total food consumption by the scavenger assemblage (Groenewold \& Fonds 2000).

The sensitivity of the bioenergetic model to Assumptions 2 to 4 above was tested by changing the parameters of current velocity, trawl catch efficiency and the proportion of discards utilized by demersal fishes. It was shown that the model was sensitive to changes in current velocity $(U)$ owing to the dominance of hagfish in the scavenger assemblage. Increasing mean $U$ by $50 \%$ decreased hagfish density so that discards could provide $53 \%$ of the seasonal requirements of scavengers. Decreasing mean $U$ by $50 \%$ reduced the potential contribution of discards to the scavenger seasonal energy requirements to $30 \%$. Real-time current velocity measurements during trap deployments would improve model estimates; however, the estimated current velocities provided were based on in situ measurements (Anonymous 2005) and are consistent with those in other areas where Myxine glutinosa are found, i.e. $0.15 \mathrm{~m} \mathrm{~s}^{-1}$ (Martini 1998).

The model was also run using scavenger densities 4 times that of trawl derived estimates (i.e. assuming $25 \%$ catch efficiency) and assuming $20 \%$ of the discard energy content was utilized by demersal fishes. Under this scenario, $24 \%$ of the seasonal energy requirements of the scavenger assemblage could still be obtained from discards. The result of the bioenergetic model is dependent on the assumptions made; however, even with conservative input parameters, the 
model demonstrates that the amount of discards arriving at the seafloor on the fishing grounds could still make a substantial contribution to the energy demand of the discard scavenger assemblage.

Liocarcinus depurator, Asterias rubens, Buccinum undatum, Neptunea antiqua, Pagurus bernhardus, Carcinus maenas and Cancer pagurus were identified as benthic discard scavengers on the Nephrops grounds, and this accords with other observations in the Irish Sea and North Sea (e.g. Nickell \& Moore 1992, Ramsey et al. 1997, Lindeboom \& de Groot 1998, Groenewold \& Fonds 2000, Bergmann et al. 2002). Nephrops have also been observed to be attracted to discards in some fisheries (Nickell \& Moore 1992, Wieczorek et al. 1999, Bergmann et al. 2002); however, there was no evidence that Nephrops fed on discards in the present study, supporting the consensus that discards are not an important dietary component of Nephrops.

The discard scavenger assemblage of the English Nephrops fishery differed from that reported for other European fisheries in 2 respects. Firstly, a paucity of small crustacean scavengers. Neither the isopod Natatolana borealis nor the amphipods Scopelocheirus hopei and Orchomene nanus, which are frequently recorded as abundant obligate scavengers, were observed: 1 or more of these species has been found in all other European studies in identifying marine discard scavengers (e.g. Lindeboom \& de Groot 1998, Groenewold 1999, Bergmann et al. 2002, Bozzano \& Sarda 2002). Nor have any of these species been observed in benthic samples from the area (Buchanan et al. 1974, Foster-Smith 2000). Secondly, the hagfish Myxine glutinosa, was present. Hagfish have been identified as discard scavengers in the NW Atlantic (Martini \& Heiser 1997) but not before in European discard studies. M. glutinosa require a particular sediment type and only occupy areas where the bottom is of clay/silt with a covering of soft, flocculent sediment into which the hagfish burrow (Martini \& Heiser 1997).

The ability of hagfish to arrive at and consume discards quickly and in large numbers could restrict access to discards for other, less mobile, benthic scavengers (Sainte-Marie \& Hargrave 1987, Nickell \& Moore 1992, Kaiser \& Spencer 1996). Hagfish are highly mobile relative to other benthic scavenging species (Foss 1968, Nickell \& Moore 1992); moreover, when feeding en masse, hagfish discourage the activity of other scavenging species by disturbing the sediment and covering the carrion in slime (Martini 1998).

The English Nephrops fishing ground was intensively fished, making $0.81 \mathrm{~g} \mathrm{~m}^{-2}$ of discards available to benthic and demersal species. This compares to 0.19 $\mathrm{g} \mathrm{m}^{-2}$ of discarded material in the southern North Sea beam trawl fishery (Groenewold \& Fonds 2000).
Therefore, both the amount of discards and the potential contribution to scavengers in this fishery were around 4 times that found in the southern North Sea (Lindeboom \& de Groot 1998). In the North Sea as a whole, the annual amount of carrion produced by fishing activities is believed to account for a maximum of $10 \%$ of annual food consumption by scavenging benthic species (ICES 2000). This study has shown that discards alone (without the inclusion of other fishery generated carrion) could provide a more substantial contribution to the energy demand of benthic scavenging populations in areas of high fishing intensity.

At the level of contribution indicated by the bioenergetic model, the amount of discards could be sufficient to allow larger populations of some benthic scavenging species to exist than would otherwise occur (Wassenberg and Hill 1987). Moreover, because the majority of fishing effort in the North Sea is confined to a small proportion of the total area (Rijnsdorp et al. 1998, Jennings et al. 1999), it follows that the enhancement of benthic scavenger populations is possible where most fishing/discarding takes place.

Acknowledgements. This research was funded by the ESRC and NERC. We acknowledge the skippers on whose vessels sampling was carried out, Alan, Chris, Dennis, Hugh, Kevin, Raymond and Ryan and their crews. We also thank the crew of the RV 'Bernicia', Ali, Kate, John and Richard, along with others who assisted on board the ship, including Susan, Phil, Kim, Paul, Silvana, Odette, Gemma, Maurica, Tim, Duncan, Liam and Heidi. We also thank Marcus and Oli for their help in collecting the trapping data. Finally, we thank the referees for their comments on the original draft.

\section{LITERATURE CITED}

Alverson DL (1997) Global assessment of fisheries bycatch and discards: a summary overview. Global Trends: Fish Manag 20:20

Alverson DL, Freeberg HH, Murawski SA, Pope JG (1994) A global assessment of fisheries bycatch and discards. FAO Fish Tech Pap 339:233

Anonymous (2005) 3D current forecasts from the Management Unit of the North Sea Mathematical Models (MUMM). Royal Belgian Institute of Natural Sciences, Brussels

Bergmann M, Moore PG (2001) Mortality of Asterias rubens and Ophiura ophiura discarded in the Nephrops fishery of the Clyde Sea area, Scotland. ICES J Mar Sci 58:531-542

Bergmann M, Taylor AC, Moore PG (2001) Physiological stress in decapod crustaceans (Munida rugosa and Liocarcinus depurator) discarded in the Clyde Nephrops fishery. J Exp Mar Biol Ecol 259:215-229

Bergmann M, Weiczorek S, Moore PG, Atkinson RJA (2002a) Utilisation of invertebrates discarded from the Nephrops fishery by variously selective benthic scavngers in the west of Scotland. Mar Ecol Prog Ser 233:185-198

Bergmann M, Wieczorek SK, Moore PG, Atkinson RJA (2002b) Discards composition of the Nephrops fishery in the Clyde Sea area, Scotland. Fish Res 57:169-183 
Birt-Friesen V, Montevecchi W, Cairns D, Macko S (1989) Activity-specific metabolic rates of free-living Northern gannets and other seabirds. Ecology 70:357-367

Bozzano A, Sarda F (2002) Fishery discard consumption rate and scavenging activity in the northwestern Mediterranean Sea. ICES J Mar Sci 59:15-28

Bridges C, Brand A (1980) Oxygen consumption and oxygenindependance in marine crustaceans. Mar Ecol Prog Ser 2:133-141

Britton J, Morton B (1994) Marine carrion scavengers. Oceanogr Mar Biol Annu Rev 32:369-434

Buchanan JB, Kingston PF, Sheader M (1974) Long-term population trends of the benthic macrofauna in the offshore mud of the Northumberland coast. J Mar Biol Assoc UK 54:56-67

Camphuysen CJ, Garthe S (2000) Seabirds and commercial fisheries: population trends in piscivorous seabirds explained? In: Kaiser M, de Groot S (eds) Effects of fishing on non-target species and habitats. Blackwell Science, Oxford, p 163-184

Camphuysen CJ, Calvo B, Durinck J, Ensor K, Follestad A and 7 others (1995) Consumption of discards by seabirds in the North Sea. Final report EC DG XIV research contract BIOECO/(93/10). Netherlands Institute for Sea Research (NIOZ) Den Burg, Texel

Catchpole TL, Frid CLJ, Gray TS (2002) Estimating Discard Quantities for the English Northeast Coast Nephrops norvegicus Fishery. Int Counc Explor Sea Comm Meet 5:33

Catchpole TL, Frid CLJ, Gray TS (2005) Discarding in the English north-east Nephrops norvegicus fishery: the role of social and environmental factors. Fish Res 72:45-54

Collins M, Yau C, Guilfoyle F, Bagley P, Everson I, Priede I, Agnew D (2002) Assessment of stone crab (Lithodidae) density on the South Georgia slope using baited video cameras. ICES J Mar Sci 59:370-379

Evans P, Kaiser M, Hughes R (1996) Behaviour and energetics of whelks, Buccinum undatum (L.) feeding on animals killed by beam trawling. J Exp Mar Biol Ecol 197:51-62

Evans SM, Hunter JE, Elizal, Wahju RI (1994) Composition and fate of the catch and bycatch in the Farne Deep (North Sea) Nephrops fishery. ICES J Mar Sci 51:155-168

Fonds M, Groenewold M (2000) Food subsidies generated by the beam-trawl fishery in the southern North Sea. In: Kaiser M, Groot SD (eds) Effects of fishing on non-target species and habitats, Blackwell Science, Oxford, p 130-150

Foss G (1968) Behaviour of Myine glutinosa L. in natural habitat; investigation of the mud biotope by a suction technique. Sarsia 31:1-13

Foster-Smith J (2000) The marine fauna and flora of the Cullercoats district. Marine species records for the North East coast of England. Penshaw Press, Sunderland

Garthe S, Hueppop O (1998) Possible biases in experiments evaluating the consumption of discards by seabirds in the North Sea. Mar Biol 131:735-741

Garthe S, Camphuysen CJ, Furness RW (1996) Amounts of discards by commercial fisheries and their significance as food for seabirds in the North Sea. Mar Ecol Prog Ser 136: $1-3$

Gnaiger E, Bitterlich G (1984) Proximate biochemical composition and calorific content calculated from elemental CHN analysis: a stoichiometric concept. Oecologia 62: 289-298

Groenewold S (1999) The effects of beam trawl fishery on the food consumption of scavenging epibenthic invertebrates and demersal fish in the southern North Sea. ICES J Mar Sci 46:1395-1406
Groenewold S, Fonds M (2000) Effects on benthic scavengers of discards and damaged benthos produced by the beamtrawl fishery in the southern North Sea. ICES J Mar Sci 57: 1395-1406

Hamilton N, Houlihan D (1992) Respiratory and circulatory adjustments during aquatic treadmill excersise in the european shore crab Carcinus maenas. J Exp Biol 162: $37-54$

Hansson S, Rudstam L, Kitchell J, Hilden M, Johnson B, Peppard P (1996) Predation rates by North Sea cod (Gadus morhua) - predictions from models on gastric evacuation and bioenergetics. ICES J Mar Sci 53:107-114

Hunt G, Kato, H, McKinnell S (2000) Predation by marine birds and mammals in the subarctic North Pacific Ocean. North Pacific Marine Science Organization PICES Scientific Rep 14:1-168

ICES (International Council for the Exploration of the Sea) (2000) Report of the working group on ecosystem effects of fishing activities. Int Counc Explor Sea Comm Meet 2:93

Jennings S, Kaiser M (1998) The effects of fishing on marine ecosystems. Adv Mar Biol 34:201-352

Jennings S, Alvsvaag J, Cotter AJR, Ehrich S and 5 others (1999) Fishing effects in northeast Atlantic shelf seas: patterns in fishing effort, diversity and community structure. III. International trawling effort in the North Sea: an analysis of spatial and temporal trends. Fish Res 40:125-134

Johnson L, Rees C (1988) Oxygen consumption and gill surface area in relation to habitat and lifestyle of four crab species. J Comp Biol Physiol A 89:243-246

Kaiser J, Spencer BE (1994) Fish scavenging behaviour in recently trawled areas. Mar Ecol Prog Ser 152:307-310

Kaiser M, Spencer B (1996) The behavioural response of scavengers to beam-trawl disturbance. In: Greenstreet $\mathrm{S}$, Tasker M (eds) Aquatic predators and their prey. Blackwell Scientific Publications, Oxford, p 117-123

Kallianiotis A, Sophronidis K, Vidoris P, Tselepides A (2000) Demersal fish and megafaunal assemblages on the Cretan continental shelf and slope (NE Mediterranean): seasonal variation in species density, biomass and diversity. Prog Oceanogr 46:429-455

Lawson J, Magalhaes A, Miller E (1998) Important prey species of marine vertebrate predators in the northwest Atlantic: proximate composition and energy density. Mar Ecol Prog Ser 164:13-29

Lee D (2001) National statistics - UK sea fisheries statistics 1999 and 2000. Department for Environment, Food and Rural Affairs, London

Lee D (2002) National statistics - UK sea fisheries statistics 2001. Department for Environment, Food and Rural Affairs, London

Lesser M, Martini H, Heiser J (1996) Ecology of the hagfish, Myxine glutinosa L. in the Gulf of Maine. I. Metabolic rates and energetics. J Exp Mar Biol Ecol 208:215-225

Lindeboom HJ, de Groot SJ (1998) IMPACT-II. The effects of different types of fisheries on the North Sea and Irish Sea benthic ecosystems. RIVO Rep. C003/98. Netherlands Institute for Sea Research (NIOZ), Den Burg, Texel

Martini F (1998) The ecology of hagfishes. In: Jorgensen J, Lombolt J, Weber R, Malte H (eds) The biology of hagfishes. Chapman \& Hall, London, p 57-77

Martini F, Heiser MLJ (1997) Ecology of hagfish, Myxine glutinosa L., in the Gulf of Maine. II. Potential impact on benthic communities and commercial fisheries. J Exp Mar Biol Ecol 214:97-106

Nickell TD, Moore PG (1992) The behavioural ecology of epibenthic scavenging invertebrates in the Clyde Sea area: laboratory experiments on attractions to bait in mov- 
ing water, underwater TV observations in situ and general conclusions. J Exp Mar Biol Ecol 159:15-35

Pearce J (1967) The feeding and reproductive biology of the red whelk, Neptunea antiqua (L.) (Gastropoda, Prosobranchia). Ophelia 4:277-314

Pedersen J, Hislop J (2001) Seasonal variations in the energy density of fishes in the North Sea. J Fish Biol 59:380-389

Pons J, Migot P (1995) Life-history of the herring gull: changes in survival and fecundity in a population subjected to various feeding conditions. J Anim Ecol 64: 592-599

Power AJ, Keegan BF, Nolan K (2002) The seasonality and role of the neurotoxin tetramine in the salivary glands of the red whelk Neptunea antiqua (L.). Toxicon 40:419-425

Ramsey K, Kaiser MJ, Moore PG, Hughes RN (1997) Consumption of fisheries discards by benthic scavengers: utilization of energy subsidies in different marine habitats. J Anim Ecol 66:884-896

Ricciardi A, Bourtget E (1998) Weight-to-weight conversion factors for marine benthic macroinvertebrates. Mar Ecol Prog Ser 163:245-251

Rijnsdorp AD, Buys AM, Storbeck F, Visser EG (1998) Microscale distribution of beam trawl effort in the southern North Sea between 1993 and 1996 in relation to the trawling frequency of the sea bed and the impact on benthic organisms. ICES J Mar Sci 55:403-419

Rumohr H (1999) Soft bottom macrofauna: collection, treatment, and quality assurance of samples. ICES Tech Mar Environ Sci 27:29

Sainte-Marie B, Hargrave B (1987) Estimation of scavenger abundance and distance of attraction to bait. Mar Biol 94: 431-443

Sarda F, Cartes JE, Company JB (1994) Spatio-temporal variations in megabenthos abundance in three different habitats of the Catalan deep-sea (western Mediterranean). Mar Biol 120:211-219

Stanley G, Hummel B, Ruesink W (1985) Estimating maximum horizontal area of pheremone plumes. J Chem Ecol 11:1129-1146

Editorial responsibility: Howard I. Browman (Associate Editor-in-Chief), Storebø, Norway
Stratoutakis Y (1999) Recommendations for improving the estimation of the number of seabirds potentially sustained by fisheries discards. Mar Ecol Prog Ser 176:307-309

Symonds DJ (1972) The fishery of the Norway lobster, Nephrops norvegicus (L.) off the north-east coast of England. Fish Investig Ser II. Minist Agric Fish Food 27:1-35

Tasker ML, Camphuysen CJ, Cooper J, Garthe S, Montevecchi W, Blaber S (2000) The impacts of fishing on marine birds. ICES J Mar Sci 57:531-547

Taylor J (1978) The diet of Buccinum undatum and Neptunea antiqua (Gastropoda:Buccinidae). J Conchol 29: 309-318

Turner D (2000) Comparison of gull numbers at Blyth South Harbour and the Tyne Estuary during 1999. In: Holliday S (ed) Blyth birds. Palm Group Advertising, Kingston-uponHull, p 120-138

Turner D (2001) Herring gulls in the mouth of the River Tyne 1999-2001. In: Bowman G, Holliday S (eds) Birds in Northumbria - The 2001 bird report for Northumberland, Newcastle and Tyneside. The Northumberland and Tyneside Bird Club, Newcastle-upon-Tyne, p 159-169

Wassenberg T, Hill B (1987) Feeding by the sand crab (Portunus pelagicus) on material discarded from prawn trawlers in Moreton Bay, Australia. Mar Biol 95:387-393

Watt A, Whitely N, Taylor E (1999) An in situ study of respiratory variables in three British sublittoral crabs with different routine rates of activity. J Exp Mar Biol Ecol 239:1-21

Wieczorek SK, Campagnuolo S, Moore PG, Froglia C, Atkinson RJ, Gramitto EM, Bailey N (1999). The composition and fate of discards from Nephrops trawlers in Scottish and Italian waters. Final Report to the European Commission. Reference 96/092, Study Project in support of the Common Fisheries Policy (XIV/96/C75). Office for Official Publication of the European Communities, Luxembourg

Yamamura O (1997) Scavenging on discarded saury by demersal fishes off Sendai Bay, northern Japan. J Fish Biol 50: 919-925

Submitted: June 24, 2005; Accepted: October 14, 2005 Proofs received from author(s): April 18, 2006 